Iğdır Üniversitesi Fen Bilimleri Enstitüsü Dergisi, 11(1): 672-685, 2021

Journal of the Institute of Science and Technology, 11(1): 672-685, 2021

ISSN: 2146-0574, eISSN: 2536-4618

Tarım Ekonomisi / Agricultural Economy

DOI: $10.21597 /$ jist.746368

Araştırma Makalesi / Research Article

Geliş tarihi / Received: 01-06-2020

Kabul tarihi / Accepted: 05-10-2020

\title{
Smartphone Application in Turkish Agriculture Sector
}

Ebru IRMAK ${ }^{1 *}$, Aydın GÜREL ${ }^{2}$, Muaffak SARIOĞLU ${ }^{3}$

\begin{abstract}
In parallel with the development of technology, there have been changes in information acquisition, communication, agricultural production and agricultural extension activities. In this context, it is important for producers to be able to carry out their plant production and animal production activities more consciously, easily or quickly. The rapid spread of smartphones and the smartphone applications developed accordingly, different applications developed by various institutions (such as public and private sector, unions and cooperatives) are a fairly new issue in terms of agricultural extension, agricultural production and digitalization in agriculture. Defining an innovation as an innovation and accepting it as the final result undoubtedly pass through some processes. In this study, the recognition of innovation is discussed. The aim of the study is examined in two ways. First, the current situation of smartphone applications in Turkey were analyzed. Which of these applications are used and which organizations serve the producers were obtained by conducting research on the internet and examining the secondary data. In the second part, which of these applications are known or used by the producers in Edirne Province Lalapaşa District were questioned on the basis of the producers. Online network was used as a method in the research. The presence of a group established by Lalapaşa producers, which is organized through Facebook, which is one of the social media channels, has made it easier to find out which smartphone applications are used. In order to determine which applications Lalapaşa producers use; 265 producers responded to the survey conducted over the group established on Facebook between January 23, 2020 and January 30, 2020. 428 people, including 392 men and 36 women, were producers in the group, and $61.92 \%$ of the producers participated in the survey. The research showed us the applications created by the public sector is more when it is compared the cooperative and private sector in Turkey. Among the applications of the public sector; it has been determined that Meteorological Condition Application, Land Registry Cadastre Parcel Query Application, and e-Goverment Application are used more than other applications.
\end{abstract}

Keywords: Smartphone, Mobile Phone, Application, Agriculture, Mobile Application, Agricultural Extension

${ }^{1}$ Ebru IRMAK $^{1}$ (Orcid ID: 0000-0002-3378-0723), Lalapaşa Tarım ve Orman İlçe Müdürlüğü Lalapaşa/Edirne, Türkiye

${ }^{2}$ Aydın GÜREL (Orcid ID: 0000-0002-8997-026X), Tekirdağ Namık Kemal Üniversitesi, Ziraat Fakültesi, Tarım Ekonomisi Bölümü, Türkiye

${ }^{3}$ Muaffak SARIOĞLU (Orcid ID: 0000-0001-8803-7139), Giresun Üniversitesi, Teknik Bilimler MYO

*Sorumlu Yazar/Corresponding Author: Ebru IRMAK¹, e-mail: ebruirmak22@hotmail.com 


\section{INTRODUCTION}

In recent years, the production and use of smart devices has been developing rapidly. Data are collected with the help of mobile phones we use, smart watches and wristbands on our wrists, electronic circuits and sensors, and these data are evaluated to improve our quality of life in different areas.

Today, software that is coded and specially designed for smart devices (smartphones and tablets) that almost everyone does not separate from their side is called "mobile application or application" (Anonymous 2020a).

These developments in smart devices have also started to be used in the agricultural sector, allowing farmers to access smart agricultural technologies. Intelligent agriculture technologies cover different areas such as remote sensing systems, autonomous agricultural vehicles, farm management systems, IOT sensors, and autonomous tractors. The purpose of smart agriculture is to make the most accurate decision about production with the data collected from the place where agricultural production is made. The right decision to be made will also mean more efficient use of agricultural inputs.

Thanks to smart farming applications, farmers can remotely control their fields via tablet or phone and can follow many processes such as irrigation, humidity and temperature with mobile applications. Efficiency and quality with internet of things; temperature and humidity values with satellite and air vehicles; autonomous vehicles and robotic systems, autonomous combine harvesters that distinguish products and stalks in the field, autonomous tractors that plow and seed the fields precisely, and agricultural machinery can be given as examples.

In addition, producers are capable of obtaining and processing large amounts of data very quickly with machine vision systems. Intelligent agricultural practices are used in the classification of products according to their size, color, strength and many other categories in the agricultural field (Uzun et al 2018).

Lanshmisudha $\mathrm{K}$ et al. (2016) call it a new revolution in agriculture to calculate soil moisture by using sensors in agriculture, to keep moisture records and to give the necessary command to open irrigation water via remote management and notifications from mobile phones.

In a study by Işık et al. (2017) on the apple plant; drip irrigation can be processed with mobile devices. Humidity sensors are placed near the root parts of apple trees in the agricultural land. According to the information received from these sensors, the irrigation status chart was created. At the end of the project, a significant advantage was achieved in the amount of water used.

There is an increasing demand for agricultural products to feed the rapidly growing world population. In order to increase productivity in the agricultural production process, it is necessary to use agricultural lands correctly, to apply smart agricultural technologies, and to reduce product losses by making data-based decisions in the logistics chain from agricultural production to consumption (Anonymous 2020b).

European Union countries prioritize digitalization as the main driver of competitiveness, economic development and employment growth (Tosheva E 2020).

The aim of this study is to determine the mobile phone applications developed for use in agriculture, to introduce these applications and to determine by which institutions they were developed. The second purpose is to determine which applications are used by the farmers of Lalapaşa district, where the rate of mobile phone usage is quite high. It is believed that this study, which is 
unique in its field, will play an enlightening role for future studies in order to develop agricultural extension in the digital environment and to move agricultural extension to the digital environment.

\section{MATERIALS AND METHODS}

\section{Materials}

The group named "Lalapaşa Agricultural Production Activities and Information" was established on Facebook by the employees of the Agriculture and Forestry District Directorate in Lalapaşa district of Edirne Province. In this group, which was established on January 31, 2017, the district governor, Lalapaşa District Directorate of Agriculture and Forestry staff, tradesmen working in the district, drug dealer owner (agricultural engineer), some lecturers from Tekirdağ Namık Kemal University Faculty of Agriculture, research institutes and active in Lalapaşa there are producers engaged in farming activities.

The total number of members is 459 as of 20 January 2020. In 2019, the number of farmers registered to the District Directorate of Agriculture and Forestry was 1551, and there are 428 producers in this group created on Facebook. In Lalapaşa, which consists of 28 villages and 1 central district, the fact that these 428 people are distributed to 29 settlements in total is especially important in terms of rapid access to information.

According to the purpose of using statistical techniques and methods, they are divided into two groups as descriptive statistics and predictive statistics. Descriptive statistics are procedures used to classify and summarize numerical data. It summarizes the data in a meaningful way, in a table, graph or numerical form. In the Turkish agricultural sector, data were prepared using the descriptive statistical method for smartphone applications. (Anonymous 2009).

The rapid spread of smartphones has improved the usability of some applications in agriculture. Approximately 30 applications have been created for use by Turkish producers today, from weather conditions, product trading, animal number inquiry to land query. Online network was used in the research. Online network; online communication; Communication via computer is expressed under various names as virtual communication or cyber communication. Using various inter-computer networks allows people to interact with each other without space and time limits. Online communication; It is also defined as the communication between two or more people through different computer applications or computers (Anonymous, 2020.c). Applications used with the help of the online network were subjected to a survey question in the Facebook group of "Lalapaşa Agricultural Production Activities and Information" from 27 January 2020 to 30 January 2020. In this way, the applications used by the Lalapaşalı producers and the application usage rates were determined.

\section{RESULTS AND DISCUSSION}

As reported by Ünal and Topakc1 (2013); the use of mobile technology in Turkey has become widespread. Especially the use of smartphones is used more actively by the young population. However, it is a well-known fact that the use of smartphones is widespread but the use of smartphone applications is not common enough.

As seen in Figure 1, the age group that uses Lalapaşa Facebook user group the most is 35-44 age group $(31.77 \%)$. This group is followed by the age range of $45-54(22.98 \%)$ and the age range of $25-$ $34(17.99 \%)$, respectively.

In a study by Şener (2009) on the use of Facebook; It was determined that the age range of 18-24 and $25-30(31.60 \%$ and $30.40 \%)$ used Facebook the most. Itcan be said that the study is compatible with the current age range of Lalapaşa Facebook users. 


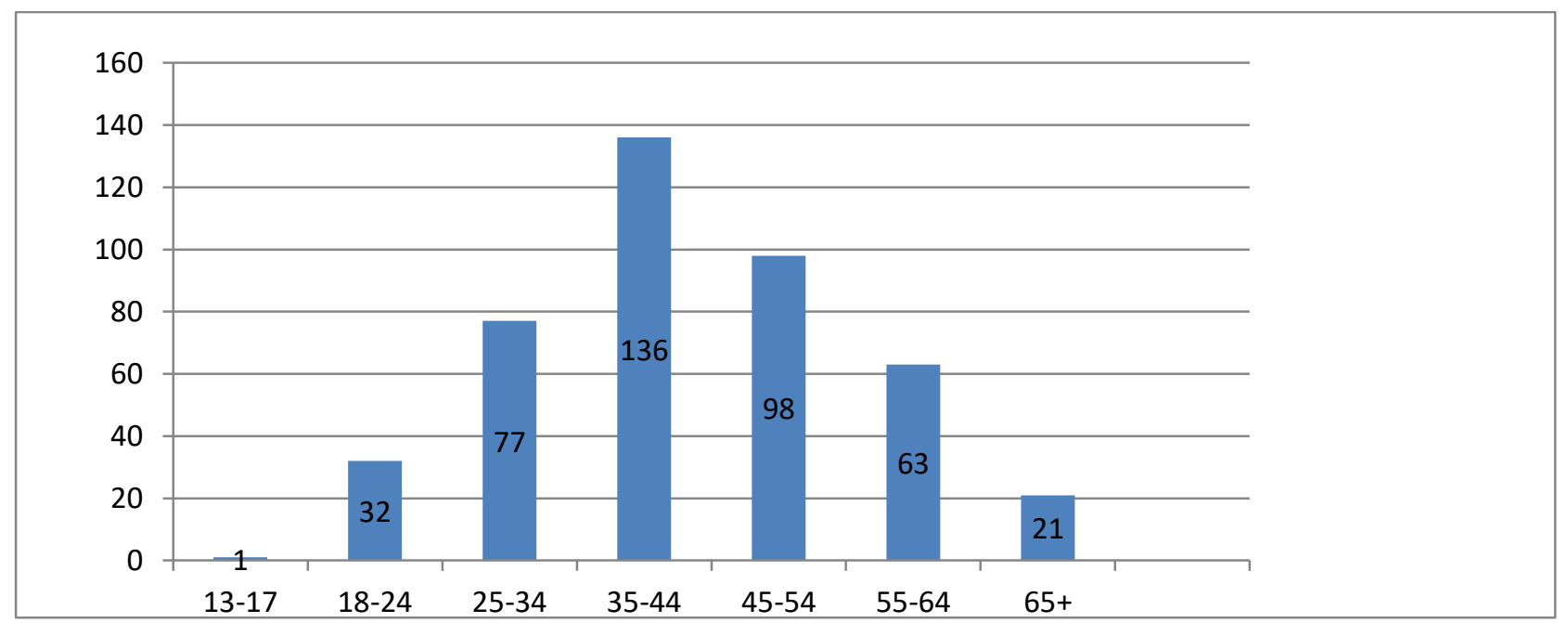

Figure 1. Lalapaşa Facebook group age diagram

In a study conducted by Y1ldiz et al. (2018) in İzmir Province Menderes District; $99.10 \%$ of the farmers own mobile phones, $72.20 \%$ smartphones and $66.90 \%$ computers. The rate of those with internet connection is $87.70 \%$. As the education level increases, the rate of internet usage increases. In addition, $85.10 \%$ of the producers included in the research have a Facebook account.

The Lalapaşa Facebook group members consist of $8.41 \%$ (36 people) female and $91.59 \%$ (392 people) male members.

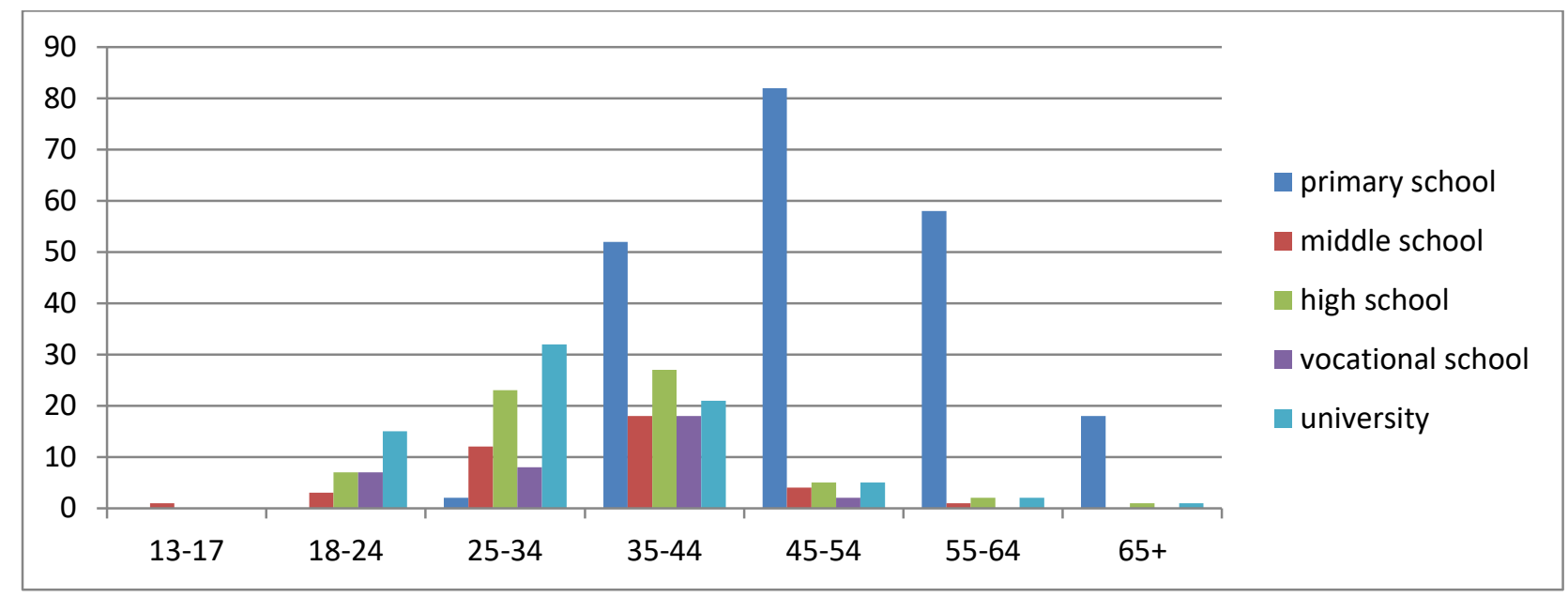

Figure 2. Lalapaşa Facebook group educational status diagram

The educational status of the Lalapaşa Facebook group is shown in Figure 2. Among the 428 people in the Facebook group, 212 people (49.53\%) attracts attention with the excess of primary school graduates. Primary school graduates are followed by undergraduates (17.89\%) with 76 people, and high school graduates (15.18\%) with 65 people.The percentage of secondary school $(9.22 \%)$ and vocational school $(8.18 \%)$ graduates are close to each other. The excess of primary school graduates will require more attention to this group in the publication studies to be carried out for the introduction and application of new technologies in agriculture. 


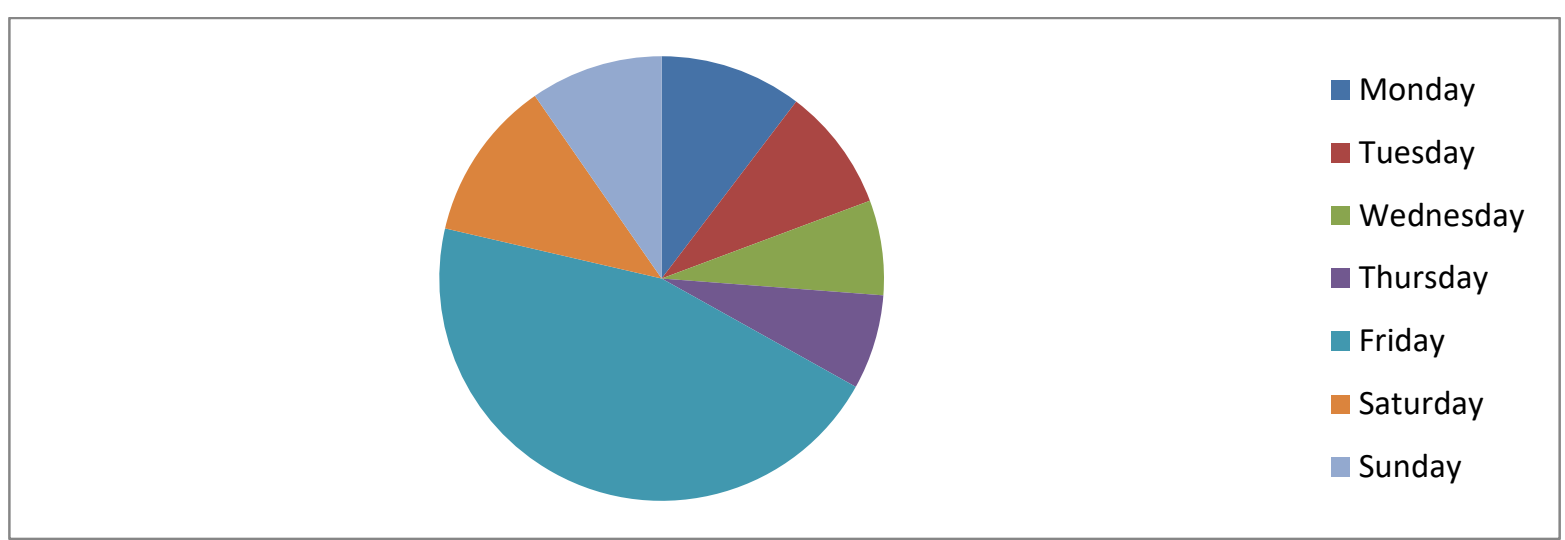

Figure 3. Days and rates used by Lalapaşa Facebook group members

The days Lalapaşa Facebook group members prefer to use Facebook can be seen in Figure 3. Common days of use; It refers to the average time that members posted, commented or left a statement. The data obtained was created as a result of the compilation of the statistical data of the last 60 days Facebook group, when more than 300 active members viewed the group content, made comments or left a statement. Friday is seen as the day that group members used the group the most $(46,00 \%)$.

Friday is one of the times considered sacred by religion (Karaman 1993). The fact that the members of the Lalapaşa group are also Muslim and that Friday is considered a blessed day by Muslims can be explained by the fact that the Facebook group is the most intense day of use.

In a study conducted by Algül (2019) on Bulgarian immigrants in Hatay's Erzin District, it was determined that the number of people coming to both mosques in the district was 44 for time prayers and 360 people for Friday prayers. Both findings are proof that the producers are devoted to the traditional structure and give a religious meaning to Fridays.

Sener (2009) as a result of his research on the use of Facebook in Turkey reveals important findings. Although Facebook usage varies according to age, gender and socioeconomic status, it has been determined that Facebook has become a part of the daily practices of users, connect to Facebook whenever users need it, and spend their free time. In addition, it has been determined that the use of Facebook is seen as a tool to maintain existing friendships rather than expanding the circle of friends.

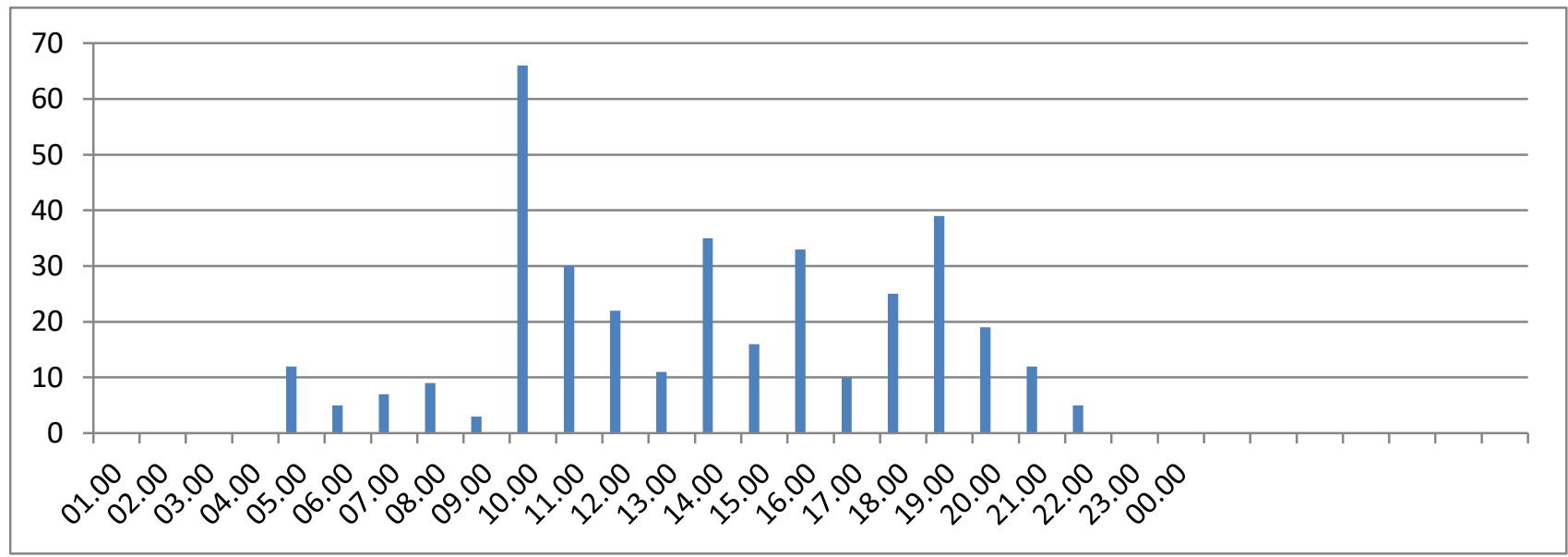

Figure 4. The hours and rates used by the Lalapaşa Facebook group members 
The hours that Facebook group members used the group frequently It refers to the average time that members posted, commented or left a statement. The data obtained were formed as a result of compiling the statistical data of the last 60 days Facebook group.

The time zones in which group members spend the most time in the digital environment are between 10.00 in the morning and 19.00 in the evening. These hours correspond to the morning and evening hours of the group members after animal care. We can say that these hours are the hours when the members of the animal care group share information about their animals with the other members of the group. Producers who wake up early in the morning are taking care of their animals after the morning prayer.

The habit of sleeping at noon is common among those engaged in agricultural activities in the district of Lalapaşa. The sleeping habit of manufacturers can be explained by the fact that they do not use the phone much between 12.00-13.00 hours.

A positive relationship was found between the level of informatics in agriculture and the factors of belonging, trust, tolerance, sharing and entrepreneurship (Karabaş and Erenler Tekmen 2019).

According to a study conducted by Google, it is stated that with "cloud computing", operating expenses will decrease by $10,00 \%$, information technology expenditures within the enterprise will decrease by $35,00 \%$, while an income of $10,00 \%$ and a productivity increase of $50,00 \%$ will be achieved (Yüksel 2012).

Table 1. Agricultural applications used in Turkey

\begin{tabular}{|c|c|c|}
\hline Implementing Agency & Application Topic & Application Name \\
\hline \multirow{13}{*}{ Ministry } & Crop production & Ministry of Agriculture plant protection application \\
\hline & Crop and animal production & Tarsim mobile application \\
\hline & \multirow{2}{*}{ Animal production } & Earring inquiry application \\
\hline & & Haysag-animal health and welfare application \\
\hline & \multirow{5}{*}{ Announcement/service } & Hunter to hunt application \\
\hline & & Ministry of Agriculture mobile application \\
\hline & & Tarbil-e farmer application \\
\hline & & TGNA Agriculture and Forestry Commission application \\
\hline & & e- Goverment application \\
\hline & Agricultural video & Farmer tv application Agriculture tv application \\
\hline & \multirow{2}{*}{ Geographic information system } & Land mobile application \\
\hline & & Land registry cadastre parcel query application \\
\hline & Meteorology & Meteorology application \\
\hline \multirow[t]{2}{*}{ Cooperative/ union } & \multirow[t]{2}{*}{ Announcement/service } & $\begin{array}{l}\text { Agricultural credit coopratives common information } \\
\text { system application }\end{array}$ \\
\hline & & TDSYMB mobile insemination application \\
\hline \multirow{12}{*}{ Private sector } & \multirow{10}{*}{ Crop production } & Hektas mobile application \\
\hline & & BAYER agriculture application \\
\hline & & Denizbank's mobile application to soil \\
\hline & & Toros farmer application \\
\hline & & Gübretaş application \\
\hline & & DOKTAR soil analysis application \\
\hline & & My Land 365 application \\
\hline & & Yield 365 application \\
\hline & & Tarbit smart farmer application \\
\hline & & Andro-Farming application \\
\hline & Agricultural video & Agriculture Turkish tv \\
\hline & Tool-equipment marketing & Agricultural market application \\
\hline
\end{tabular}

Cloud computing technology, on which the information sector has been working extensively recently, may be a solution to the needs of the agricultural sector (Ünal and Topakc1 2013) 
The use of mobile technology in Turkey in recent days has become widespread. It is observed that the use of smartphones has increased, especially among young people. Despite the widespread use of smartphones, we cannot say that the use of smartphone applications is common enough.

In a study conducted by Gülter and his friends in İzmir Province Menderes District (2018); farmers' cell phone usage levels were found satisfactory. It has been determined that the farmers' ability to send messages on their mobile phones, take photos, use WhatsApp, share photos from their mobile phones, and become members of WhatssApp groups and establish groups are at a good level.

Among the reasons why producers cannot use applications related to agriculture; The fact that smartphone applications do not have sufficient Turkish usage features and that these applications are not promoted sufficiently to farmers can be counted. It can be said that social and economic welfare in the agricultural sector will improve with the preparation of Turkish-based smartphone applications used in agriculture and the widespread use of these applications by farmers (Haciyusufoğlu \& Güler, 2016).

As reported by Tekin (2018), smart agriculture is not a choice but a necessity in agricultural production.

According to the data obtained as a result of the internet research, organizations that develop and implement smartphone applications in agriculture generally; It is possible to examine them in 3 groups as ministries (Ministry of Agriculture and Forestry, Ministry of Interior, Ministry of Environment and Urbanization), cooperatives / unions and private sector. These applications and their contents are listed ebow (Table 1).

Ministry of Agriculture, Plant Protection Application: The plant Protection products tracking system contains to computers, databases, computer software and communication infrastructures that use this database to enable the tracking of plant protection products, which have been traceable with square codes, from every point starting from production or import is a system (Anonymus 2020c).

Mobile Application of the Ministry of Agriculture: Announcements, working subjects, activities, contact information etc. of all units affiliated to the Ministry. All contents can be accessed quickly and the agenda of the agriculture can be followed instantly with notifications (Anonymous, 2020ç).

Earring Inquiry Application: Our country cattle, sheep and goats are recorded in the national database. Animal movements and diseases can be monitored though the registration system. It is an application used to inquire the species, race, gender and date of birth of the animals registered in the registration system (Anonymous, 2020d).

Haysag- Animal Health and Welfare Application: It s an application developed for smart devices in order to facilitate citizens'access to healthy animals. Information about the animal can be displayed by entering the earring number of the animal purchased of desired (Anonymous, 2020e).

Hunter to Hunt Application: It is an application for hunters who have received a hunting certificate according to the land hunting law (Anonymous, 2020f).

Tarbil-e Farmer Application: It is the area where all kinds of activities and applications can be made on crop production, animal production and geographical information system (Anonymous, 2020g).

Turkish Grand National Assembly (TGNA), Agriculture and Forestry Commission Application: It is a specialized commission that operates in accordance with the TGNA Rules of Procedure. It discusses the law proposals on agriculture, forestry, animal husbandry, land use, land protection and regulation of village life and similar issues referred to it by the Presidency of the TGNA. (https://komisyon.tbmm.gov.tr/komisyon_index.php?pKomKod=33) 
Tarsim Mobile Application: It is the application used to reach agricultural insurance applications via smartphones and tablets, independent of location and time, and to ensure sustainability in communication with stakeholders (Anonymous, 2020 g).

Land Mobile Application: A mobile application developed for the Project contractors and ministry personnel to collect data from the field based on form (Anonymous, 2020h).

Land Registry Cadastre Parcel Query Application (TAKBİS): All 957 land registry offices operating thoughout the country were put into operation as of May 1, 2012 and all deed transactions were made to citizens though this system (Anonymous, 20201).

Meteorology Application: This application is developed that can be achieved instant climate data for all provinces and certain district in Turkey (Anonymous, 2020i).

e- Goverment Application: It means that the services provided by the state to citizens are electronically. In this way, it is aimed to provide public services to citizens in the easiest and most effective way, in a quality, fast, uninterrupted and secure way (Anonymous, 2015).

Farmer TV Application: It is an application developed to be aware of all kinds of news about agriculture and animal husbandry (Anonymous, 2020j).

Agriculture TV Application: It is an application that the Ministry provides services on weather and agriculture calender (Anonymous, 2020k).

Tarbit Smart Farmer Application: It is an application that server 1 million 600 thousand farmers. An application that provides services for every part of the sector (farmers, cooperatives and associations, companies, public, academics, students, municipalities) (Anonymous, 20201).

Agricultural Credit Cooperatives Common Information System Application: It has objectives such as conducting various works related to the cooperative in mobile environment, strenghthening the communication by giving interactive sharing, announcing the organizational activities by displaying many information in the cooperative (Anonymous, 2020m).

TDSYMB (Cattle Breeders' Association of Turkey) Mobile Insemination Application: Cattle Breeders' Association of Turkey is the mobile seeding program that allows the artificial insemination of that veterinarians do and automatic recording of seeding practitioners (Anonymous, 2020n).

HEKTAS Mobile Application: Application of plant protection drugs for sale from a mobile application. Agricultural producers; by sharing personal information from Hektaş Mobile, can send photos of pests and diseases encountered in the field or garden directly from their mobile device and get expert opinion (Anonymous, 2020o).

BAYER Agriculture Application: Specially developed for producers and agricultural professionals, Bayer agriculture application is an application where they can learn the most accurate BAYER products against disease, pests and weeds. In addition, Bayer Crop Science provides access to all plant protection medicines, product labels, brochures and safety data sheets as soon as possible (Anonymous, 2020ö).

Denizbank's Mobile Application to Soil: In Turkey with special programs prepared by the expert team of more than 100 cultivated area suitable for agricultural products fumigation, fertilization, irrigation, planting and harvesting advice comes to your mobile device. These notifications aim to achieve more efficiency by spending less (Anonymous, 2020p).

Toros Farmer Application: Toros farmer intelligent agriculture and fertilization application which was developed by Toros agriculture specifically fors mart phones and tablets and offered to farmers free of charge, combines weather forecast soil and plant data and develops suggestions for farmers' activities support application (Anonymous, 2020r). 
Agricultural Market Application: It is the application that enables online sales of all kinds of agricultural tools and machinery (Anonymous, 2020s).

Turkish Agricultural tv: It has started broadcasting on 12.10.2011, it is an application that contains various videos fort he producer (Anonymous, 2020ş).

Gübretaş Fertilizer Application: It is an application that provides plant nutrion and consultancy services for farmers. It also responds to farmers' problems instantly (Anonymous, 2020u).

DOKTAR Soil Analysis Application: DOKTAR is an institution that provides agricultural extension and consultancy services to producers. This practice is based on the logic of scanning the soil 5 times with infrared rays and loading the results into this application (Anonymous, 2020ü).

My Land 365 Application: It can benefit from information services such as fertilizer, diesel oil, medicine, market/ stock exchange prices, and the producers plans can be made accordingliy, instantly informed of the grant/ support announcements. Annual drought and risk (hail, lightning) reports can be accessed, product based breeding suggestions can be browsed, use time more effectively by using spraying time warning, and the status of crops can be monitored instantly with satellite- supported product tracking (Anonymous, 2020v).

Yield 365 Application: It provides irrigation and fungal disease management though collected soil (heat and humidity) and air (soil temperature and humidity) data (Anonymous, 2020y).

Andro- Farming application: this application has been developed in a way to provide the service of learning the precipitation, moisture and temperature information of the farmers, where the planting and harvesting efficiency of the farmers are recorded, and the yields are displayed by years (Hacıyusufoğlu and Güler 2015).

Agricultural producers in the Lalapaşa Facebook group were asked which of the above mentioned applications they use. It was observed that a total of 265 manufacturers answered the questionnaire. This number shows that $61.90 \%$ of the group members participated in the survey. In the survey study conducted over a single question, among the 30 applications used today, which of the Lalapaşa producers use, the following findings were obtained (Table 2).

Table 2. Applications used by Lalapaşa producers of Edirne province

\begin{tabular}{lcc}
\hline Name of Application & Number of Producers & Percentage (\%) \\
\hline Meteorology Application & 63 & 23,7 \\
Land Registry Cadastre Parcel Query Application & 59 & 22,3 \\
e- Goverment Application & 57 & 21,5 \\
Earring Inquiry Application & 37 & 14,0 \\
Farmer TV Application & 21 & 7,9 \\
Agriculture TV Application & 21 & 7,9 \\
Hunter to Hunt Application & 7 & 2,7 \\
\hline TOTAL & $\mathbf{2 6 5}$ & $\mathbf{1 0 0 , 0}$ \\
\hline
\end{tabular}

According to Table 2, it has been determined that all of the producers use only applications developed by the public sector (Ministry of Agriculture and Forestry, Ministry of Interior, Ministry of Environment and Urbanization). It is determined that the smartphone application used by the producers mostly in agricultural production is the meteorology application $(23.70 \%)$. The fact that dry farming practices are dominant in Lalapaşa and that the producers are highly dependent on climatic conditions in their agricultural activities are the indications that this application is the most preferred application.

In a study conducted by Yıldiz et al. In İzmir Province Menderes District (2018); The purposes of farmers to use the internet are determined as weather conditions, technical information for 
agricultural purposes, agricultural struggle, information about supports and others. The information most needed by the producer was found as meteorology data in both studies.

Land registry cadastral parcel query application is used at the rate of $22,30 \%$. It is an application that is frequently used by the producer in works and processes such as continuing land consolidation operations in Lalapaşa, land purchase-sale works, correction of cadastral errors.

The usage rate of the e-government application by the producers is $21.50 \%$. e-government application is a frequently used application by Lalapaşa producers especially in the young group (1845) age range.

It has been determined that producers use earring inquiry application (14.00\%) in animal production activities. The fact that bilateral diologists of agricultural district veterinarians and producers are high and the habit of the producer coming to the district directorate of agriculture and carrying out his work and transactions may be effective on this rate.

The number of producers using farmer tv and agriculture tv applications is the same and this number corresponds to $7,90 \%$ proportionally. These applications are mostly applications that contain videos on agricultural issues.

The application percentage of Lalapaşa producer for hunter to hunt application, which is used as a legal requirement for hunting sports, has been found as 2.70 . This result can be considered as an indication that the respondents are not very interested in hunting activities.

According to a research conducted by Akin et al in 2014; while the rate of farmers who had smartphones was $0.01 \%$ in 2010, this rate increased over the years and increased to $38.00 \%$ in 2014 , which shows that the use of smartphones in the agricultural sector is open to development. The scarcity of agricultural practices in the use of smartphones at the time of the research and the tendency of the farmers not to need such practices caused the positive developments in technology to not turn into productivity.

According to a research conducted in Lalapaşa district (Irmak 2019); the average age of the producers was found to be 53.40. In the field of research, $0.90 \%$ of the producers are literate, $61.30 \%$ are primary school graduates, $19.50 \%$ secondary school graduates, $11.30 \%$ high school graduates, $3.20 \%$ has associate degree, $3.30 \%$ has graduate degree, and $0.50 \%$ has post graduate degree.

$96.80 \%$ of the producers in Lalapaşa use mobile phones and $51.30 \%$ can use the internet (Irmak E. 2019). When the results obtained in 2019 are compared with the study conducted in 2010, it proves that there is an improvement in the application rate of producers.

\section{CONCLUSION}

In Turkey; there are applications for agricultural activities developed by the private sector, cooperatives and the public. Proportionally, the majority of these developed applications belong to the public sector. Application services provided by the public sector; has focused on subjects such as plant and animal data statistics, announcement / announcement, e-education, geographical information system, daily climate data. These applied data are very important for the producers. However, these applications, which are mainly given by the public sector, cannot meet the technical dimension of the work in agricultural production. The private sector is in a position to play a key role in providing technical services by mobile phone applications. It is seen that agricultural applications developed abroad are mostly developed by the private sector and include the technical dimension of agriculture. This is because it can be said that agricultural extension activities around the world are on the way to privatization. 
It was found that Lalapaşa producers were not aware of practices other than those developed by the public sector. In this context, especially the private sector and cooperatives in Turkey are required to make a variety of extension work for the introduction and acceptance of agricultural innovation.

Information, independent of working hours or biological hours, is shared via smartphones. It has been revealed by the research that it may be appropriate to make these shares on Fridays in order to be effective on the target audience. In addition, it was determined by the research that the posts to be made after 09.00 in the morning and after 19.00 in the evening would be perceived better by the producers, attracted attention or could be read by allocating time.

The use of technology in agricultural production is spreading rapidly in developed countries. In this way, water and fertilizers can be used as much as the plant needs and the inputs are used to provide maximum benefit. Such practices increase the profit margin in crop production, prevent excessive use of inputs, and enable more environmentally sensitive agriculture. In this context, it is beneficial for the private sector to quickly adopt these technologies to producers. In addition, the Lalapaşa producer's use of the internet and smartphones, its need for information and its readiness to use technology positively affect private companies' involvement in this issue.

When we look at the use of smartphone applications in agriculture, considering that the average age of Turkish farmers is high and the education level is partially low, some regulations need to be made in the programs used in these phones in order to popularize smartphone applications in the agricultural sector. In the arrangements to be made; there should be applications such as visuality (such as video, photo) being at the forefront, easy usage language, if possible not asking for a password for security reasons or a very simple password, and the program language being Turkish.

\section{REFERENCES}

Anonim,

2009.

İstatistik

Ders

Notu. https://personel.omu.edu.tr/docs/ders_dokumanlari/9330_54507_1642.pdf (Erişim tarihi: 01 Ekim 2020).

Anonim, 2020a. Mobil Uygulama Nedir? https://egegen.com/blog/mobil-uygulama-nedir/ (Erişim tarihi: 29 Ocak 2020).

Anonim, 2020c. https://cevrimiciiletisim.wordpress.com/2017/12/20/cevrimici-iletisim-nedir/ Erişim Tarihi: 03 Eylül 2020).

Akın T, Yıldırım C, Çakan H, 2014. Tarımsal Pazaryeri. Tabit.com.tr (Erişim Tarihi: 27 Ocak 2020).

Algül İ, 2019. Bulgaristan Göçmenlerinin Dini İnanç ve Uygulamaları Üzerine Sosyolojik bir Araştırma: Hatay-Erzin'de yaşayan göçmenler Örneği. T.C. Bursa Uludağ Üniversitesi Sosyal Bilimler Enstitüsü, Felsefe ve Din Bilimleri Anabilim Dalı, Din Sosyolojisi Bilim Dalı, Bursa, Yüksek Lisans Tezi.

Anonim, 2015. E-Devlet nedir? E-Devlet ile Hangi Hizmetlerden Yararlanılır? http://www.hurriyet.com.tr/gundem/e-devlet-nedir-e-devlet-ile-hangi-hizmetlerden-yararlanilir30264995 (Erişim tarihi: 27 Ocak 2020).

Anonim, 2020a. Verim 365 uygulaması. https://www.doktar.com/ (Erişim tarihi: 27 Ocak 2020).

Anonim, 2020b. Tarım Teknolojileri ile Tarımda Fark Oluşturmak https://www.tarnet.com.tr/blog/makale/tarim-teknolojileri-ile-tarimda-fark-olusturmak/ (Erişim tarihi: 03 Eylül 2020,)

Anonim, 2020e. Kurbanlık Sorgulama HaySag nedir? Nasıl İndirilir? Küpe sorgulama HaySag Uygulamas1. https://www.sonhaberler.com/kurbanlik-sorgulama-haysag-nedir-nasil-indirilirkupe-sorgulama-haysag-uygulamasi-haber-650779 (Erişim tarihi: 27 Ocak 2020). 
Anonim, 2020f. Ava Avc1 Uygulamas1. https://www.google.com.tr/search?source=hp\&ei=dswuXtTPMsGVkwXq1arICQ\&q=Ava+avc $\% \mathrm{C} 4 \% \mathrm{~B} 1+$ uygulamas $\% \mathrm{C} 4 \% \mathrm{~B} 1+$ nedir\&oq=Ava+avc\%C4\% $1+$ uygulamas $\% \mathrm{C} 4 \% \mathrm{~B} 1+$ nedir\&gs _l=psy-ab.3...2403.7536..7982...0.0..0.291.1263.0j7j1.....0...2j1..gws-

wiz....8..0i362i308i154i357j0j0i22i30j33i22i29i30j33i160.sDgCk7d61QQ\&ved=0ahUKEwjU4 oC72aPnAhXByqQKHeqqCpkQ4dUDCAY\&uact=5 (Erişim tarihi: 27 Ocak 2020).

Anonim, 2020g. E-Çiftçi Portalına Hoşgeldiniz. https://eciftci.tarbil.gov.tr/ (Erişim tarihi: 27 Ocak 2020).

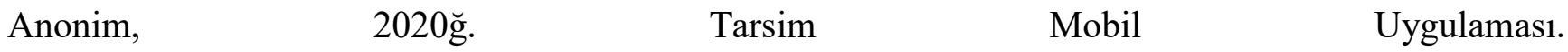
https://www.google.com.tr/search?ei=88wuXtOHDOTagwfrgYTYDA\&q=Tarsim+mobil+uygul amas\%C4\%B1+nedir\&oq=Tarsim+mobil+uygulamas\%C4\%B1+nedir\&gs_l=psyab.3...2985.2985..4119...0.1..0.419.419.4-1.....0....2j1..gws-wiz.......0i71.5xQOWvyg9g\&ved=0ahUKEwiTzaf22aPnAhVk7eAKHesAAcsQ4dUDCAs\&uact=5 (Erişim tarihi: 27 Ocak 2020).

Anonim, 2020h. Arazi mobil uygulamas1. https://www.google.com.tr/search?ei=Mc0uXpjeM5CtUvrppqgN\&q=Arazi+mobil+uygulamas\% $\mathrm{C} 4 \% \mathrm{~B} 1+$ nedir\&oq=Arazi+mobil+uygulamas\%C4\%B1+nedir\&gs_l=psy-

ab.12..86444.86444..87990...0.1..0.109.109.0j1.....0....2j1..gwswiz......0i71.1OufpayyUyo\&ved=0ahUKEwjYupeU2qPnAhWQlhQKHfq0CdUQ4dUDCAs (Erişim tarihi: 27 Ocak 2020).

Anonim, 20201. Tapu ve Kadastro Genel Müdürlüğü. https://www.tkgm.gov.tr/tr/icerik/parselsorgulama-3 (Erişim tarihi: 27 Ocak 2020).

Anonim, 2020i. Meteoroloji uygulamas1. https://www.google.com.tr/search?ei=zM0uXoGyNavMgwe6p7fwBA\&q=Meteoroloji+durumu +uygulamas\% $\mathrm{C} 4 \% \mathrm{~B} 1+$ nedir\&oq=Meteoroloji+durumu+uygulamas $\% \mathrm{C} 4 \% \mathrm{~B} 1+$ nedir\&gs_l=psyab.12...4234.4234..6384...0.1..0.105.105.0j1.....0...2j1..gws-

wiz.......0i71.f1TihgNzdO8\&ved=0ahUKEwiByI3e2qPnAhUr5uAKHbrTDU4Q4dUDCAs (Erişim tarihi: 27 Ocak 2020).

Anonim, 2020j. Çiftçi tv uygulamas1. https://www.google.com.tr/search?source=hp\&ei=sNMuXoHXG82MrwSF35CADg\&q=\%C3\% 87ift $\% \mathrm{C} 3 \% \mathrm{~A} 7 \mathrm{i}+\mathrm{tv}+$ uygulamas $\% \mathrm{C} 4 \% \mathrm{~B} 1+$ nedir\&oq $=\% \mathrm{C} 3 \% 87 \mathrm{ift} \% \mathrm{C} 3 \% \mathrm{~A} 7 \mathrm{i}+\mathrm{tv}+$ uygulamas $\% \mathrm{C} 4$ $\%$ B1+nedir\&gs_l=psy-ab.3...2257.6286..6839...0.0..0.225.1302.0j6j2.....0....2j1..gwswiz.....8..0i362i308i154i357j33i160j0i22i30j33i22i29i30.A55ngvr8_wE\&ved=0ahUKEwiB7_ys 4KPnAhVNxosKHYUvBOAQ4dUDCAY\&uact=5 (Erişim tarihi: 27 Ocak 2020).

Anonim, 2020k. Tarım tv. https://www.tarimtv.gov.tr/ (Erişim tarihi: 28 Ocak 2020).

Anonim, 20201. Tabit. http://www.tabit.com.tr/ (Erişim tarihi: 27 Ocak 2020).

Anonim, 2020m. E-Koop. https://www.tarnet.com.tr/cozumlerimiz/sektorel-cozumler/e-koop/ (Erişim tarihi: 27 Ocak 2020).

Anonim, 2020n. TDYSMB mobil tohumlama uygulamas1. https://www.google.com.tr/search?ei=udQuXqmgD6XVgwfezongAw\&q=TDYSMB+mobil+toh umlama+uygulamas\%C4\%B1+nedir\&oq=TDYSMB+mobil+tohumlama+uygulamas $\% \mathrm{C} 4 \% \mathrm{~B} 1+$ nedir\&gs_l=psy-ab.3...18043.19677..20171...0.2..0.166.883.0j6.....0....1..gwswiz......0i71j33i160.qW-

VtR6azP4\&ved=0ahUKEwjp4J6r4aPnAhW16uAKHV5nAjwQ4dUDCAs\&uact=5 (Erişim tarihi: 27 Ocak 2020). 
Anonim, 2020o. HEKTAŞ mobil uygulamas1. https://www.hektas.com.tr/hektas-akilli-asistan/314 (Erişim tarihi: 27 Ocak 2020).

Anonim, 2020ö. BAYER Çözümleri Cebinizde. https://www.tarim.bayer.com.tr/tr/bayer-cozumlericebinizde.php (Erişim tarihi: 27 Ocak 2020).

Anonim, 2020p. Deniz'den Toprağa Platformu. https://www.denizbank.com/denizden-topragauygulamasi/ (Erişim tarihi: 27 Ocak 2020).

Anonim, 2020r. Toros çiftçi uygulaması. https://www.google.com.tr/search?ei=rNUuXraoKrGjLsPnPyesAk\&q=Toros+\%C3\%A7ift\%C3\%A7i+uygulamas\%C4\%B1+nedir\&oq=Toros+\%C3 $\% \mathrm{~A} 7 \mathrm{ift} \% \mathrm{C} 3 \% \mathrm{~A} 7 \mathrm{i}+$ uygulamas\%C4\%B1+nedir\&gs_l=psyab.12...3261.3261..4018...0.1..0.108.10 $8.0 \mathrm{j} 1 \ldots . . .0 . . .2 \mathrm{j} 1 . . \mathrm{gws}-$ wiz......0i71.fsk6iQMBvCY\&ved=0ahUKEwi2rqmf4qPnAhU_A2MBHRy-B5YQ4dUDCAs (Erişim tarihi: 27 Ocak 2020).

Anonim, 2020s. Zirai Pazar. https://www.ziraipazar.com.tr/ (Erişim tarihi: 27 Ocak 2020).

Anonim, 2020ş. Tarım Türk. http://tarimturktv.com/ (Erişim tarihi: 27 Ocak 2020).

Anonim, 2020t. Tüccarım- Hayvancilıkta Alım Satım Uygulaması. https://play.google.com/store/apps/details?id=com.ecloud.tuccarim\&hl=tr (Erişim tarihi: 27 Ocak 2020).

Anonim, 2020u. Gübretaş, Çiftçiyi Cepten Bilgilendirme. https://www.gubretas.com.tr/gubretasciftciyi-cepten-bilgilendirecek/ (Erişim tarihi: 27 Ocak 2020).

Anonim, 2020ü. Digital Toprak Analizi. https://doktar.com/tr/dijital-toprak-analizi (Erişim tarihi: 27 Ocak 2020).

Anonim, 2020v. Tarlam 365 uygulaması. https://www.doktar.com/ (Erişim tarihi: 27 Ocak 2020).

Gülter S, Yıldız Ö, Boyacı M, 2018. Çiftçilerin Bilgi ve İletişim Teknolojilerini Kullanma Eğilimleri: İzmir İli Menderes İlçesi Örneği. Tarım Ekonomisi Dergisi, cilt 24, say1:2 syf:131-143.

Hacıyusufoğlu, A. F, Güler E, 2016. Tarımda Mobil Uygulamalar, 18.Akademik Bilişim Kongresi, Aydin.

Hacıyusufoğlu, A. F, Güler, E, 2016. Tarımda Mobil Uygulamalar, 18.Akademik Bilişim Kongresi, Aydin.

Irmak E, 2019. Tarım Kooperatiflerinde Yayım Yaklaşımları: Edirne İli Lalapaşa İlçesi Örneği. Doktora Tezi, Fen Bilimleri Enstitüsü, Tekirdağ Namık Kemal Üniversitesi.

Işık M, Yılmaz C ve Işık E, 2017. Tarımsal Arazi Sulama Sistemlerinde Mobil Uygulamalar Örnek bir Çalışma. Politeknik Dergisi 20 (3), 725-731.

Karabaş, S, Erenler Tekmen E, 2019. Tarım Sektöründe Sosyal Sermaye ve Bilişim Teknolojileri Kullanım Düzeyi. Uluslararası Sosyal Araştırmalar Dergisi. Cilt 12, Sayı 62

Karaman H, 1993. Cuma. Türkiye Diyanet Vakfi İslam Ansiklopedisi İstanbul Türkiye Diyanet Vakfı İslam Araştırmaları Merkezi c:8 s: 85:89.

Lanshmisudha K, Hegde S, Kale N, Iyer S, 2016. Smart Precision Based Agriculture Using Sensors. International Journal of Computer Applications (0975-8887) Volume 146- no:11, July 2016.

Şener G, 2009. Türkiye'de Facebook Kullanımı Araştırması. XIV.Türkiye'de İnternet Konferansı Bildirimleri. 12-13 Aralık 2009, Bilgi Üniversitesi, İstanbul.

Tarım ve Orman Bakanlığı, 2020c. Bitkisel üretim bitki sağlığı- bitki koruma ürünleri uygulama belgesi. https://istanbul.tarimorman.gov.tr/Sayfalar/Detay.aspx?SayfaId=155 (Erişim tarihi: 27 Ocak 2020). 
Tarım ve Orman Bakanlığı, 2020ç. Tarım Bakanlığı Mobil uygulamaları yayınlanmıştır. https://vskn.tarimorman.gov.tr/antalya/Haber/6/T-C-Gida-Tarim-Ve-Hayvancilik-BakanligiMobil-Uygulamalari-Yayimlanmistir (Erişim tarihi: 27 Ocak 2020).

Tarım ve Orman Bakanlığı, 2020d. Küpe sorgulama. https://hayvanbilgi.tarim.gov.tr/ (Erişim tarihi: 27 Ocak 2020).

Tekin A.B, 2018. Tarımsal Üretimin Geleceği: Akıllı Tarım. Türktob dergisi sayı:26, syf 26-27.

Tosheva E, 2020. Economic and Social Benefits of Digital Economy and Digital Transformation in the Republic of North Macedonia. İzmir Sosyal Bilimler Araştırma Dergisi, Aralık 2020, cilt 2, say12, syf 42-51.

Uzun Y, Bilban M. ve Arıkan H, 2018. Tarım ve Kırsal Kalkınmada Yapay Zeka Kullanımı. VI. Kop Bölgesel Kalkınma Sempozyumu- KOPBKS 26-28 Ekim 2018, Konya.

Ünal İ, Topakcı M, 2013. Tarımsal Üretim Uygulamalarında Bulut Hesaplama ( Cloud Computing) Teknolojisi. Akademik Bilişim 2013- Xv. Akademik Bilişim Konferansı Bildirileri 23-25 Ocak 2013- Akdeniz Üniversitesi, Antalya.

$\begin{array}{llllll}\text { YÜKSEL H, } & \text { 2012. } & \text { Bulut } & \text { Bilişim } & \text { El } & \text { Kitabı. }\end{array}$ https://yukselis.files.wordpress.com/2012/01/bulutbilic59fimelkitabc4b1.pdf (Erişim tarihi: 27 Ocak 2020). 